Kosztopulosz Andreász - Kuruczleki Éva (szerk.) (2020): Társadalmi és gazdasági

folyamatok elemzésének kérdései a XXI. században. Szegedi Tudományegyetem

Gazdaságtudományi Kar, Szeged, https://doi.org/10.14232/tgfek21sz.4

\title{
A visegrádi országok jelenlegi fiskális keretrendszere
}

\author{
Sávai Marianna
}

A visegrádi országok közös jellemzője, hogy a fiskális politika „,húzd meg, ereszd meg” politikájának köszönhetö GDP ingadozás és a látszólag magas növekedési potenciál az uniós szabályoknak való megfeleléssel párosult a rendszerváltozásuk óta. Ezen hasonlóságok és az esetleges különbségek fiskális keretrendszerre gyakorolt hatásának kirajzolása a célja a tanulmánynak. Kiemelve az időszak azon eseményeit és az országok sajátos gazdaságpolitikai helyzetét, amely a jelenlegi fiskális keretrendszer kialakulására hatással volt. A keretrendszer időbeli fejlödésének alakulását összegzem, melyben nemcsak a fiskális szabályok, hanem a független fiskális intézmények kialakitására is kitérek. Az országok fiskális keretrendszerét az Európai Unió értékelési rendszerében elfoglalt helyezések alapján is összehasonlitom.

Kulcsszavak: fiskális keretrendszer, fiskális szabály, fiskális szabályok indexe

\section{Bevezetés}

A visegrádi országok kis nyitott gazdaságok, ezért számos ebből az állapotból származó hasonlóságot figyelhetünk meg bennük. A fejlett országokhoz képest a külföldi müködőtőke-beáramlástól való függőség nagyobb, jelentősebb a fizetésimérleg-hiány, alacsonyabb az adópotenciál az adóelkerülés miatt, és az állóeszközök alacsony szintje, a munkaerö-piaci problémák és az alulfinanszírozás nagyobb állami kiadási feszültségekhez vezet. További közös jellemzőjük, hogy a fiskális politika „húzd meg, ereszd meg” politikájának köszönhető a GDP ingadozása, valamint a látszólag alacsony államadósság és magasabb növekedési potenciál (ÓdorP. Kiss 2011). Tehát egy érdekes téma feltárni azon összefüggéseket, amelyek mentén ezen országok felépítették a fiskális fenntarthatósághoz elengedhetetlen fiskális keretrendszerüket. A tanulmány kutatási kérdése tehát arra keresi a választ, hogy mennyiben hasonlítanak egymásra a visegrádi országok fiskális keretrendszerei.

A visegrádi országok specialitása a kilencvenes évek nagy részét felölelö tranzíciós folyamat, amelyben a teljes intézményrendszert át kellett alakítaniuk a piacgazdaság és a későbbi Európai Uniós csatlakozás kívánalmainak megfelelően. Az egykori keleti blokk többi országához viszonyítva képesek voltak megfelelni ennek. Mindeközben a korábbi rendszertöl örökölt, illetve az átalakulás sokkja nyomán létrejövő államadósságot is menedzselniük kellett. Ez a példátlan, sokszor kormányzati ciklusokon átívelő konszolidációs feladat egyaránt szólhatott mind a napi müködőképesség fenntartásáról mind a hosszú távú stratégiai célok eléréséről. Ilyen feltételek mellett fennálltak feszültségek az államadósság fenntarthatóságának megvalósulása esetében is.

A keretrendszer időbeli kialakulását és jelenlegi állapotát jól átlátható ábrába és táblázatokba rendezve országonként mutatom be az egyes fejezetekben, melyekben nemcsak a szabályokra, hanem a független fiskális intézményekre is kitérek. Az 
országok helyzetének bemutatását követően az Európai Unió által alkalmazott értékelési rendszer alapján kerülnek összehasonlításra az országok, majd összegzéssel zárul a tanulmány.

\section{Csehország fiskális keretrendszere}

Csehország a rendszerváltozását követően kismértékü államadóssággal rendelkezett, ami mára már megkétszereződött, de még így is alacsonyabb, mint a maastrichti kritériumok által meghatározott 60 százalékos határ, így hosszú ideig nem foglalkoztak a fiskális szabályok és a független fiskális intézmények bevezetésének kérdésével. Viszonylag egyszerü fiskális szabályokat már 2000-től bevezettek, amelyek a nem várt negatív sokkhatások esetén a kiadásokra és a bevételekre vonatkozó előírásokat tartalmaztak. A következő évtől a költségvetés tervezési időszakát is kiterjesztették gördülő hároméves folyamattá. 2003-tól a pénzügyminiszter javaslatára a kabinet hozhat döntést a deficit, aggregált bevétel és kiadás, valamint a kiadási prioritások összegének célértékéről (Yläoutinen 2004). A 2017. évi fiskális jelentésükben megjelenik egy fiskális intézményekre vonatkozó vizsgálat, ami azt mutatta, hogy a cseh kormánynak is érdeke valamilyen független fiskális intézmény létrehozása a jövőben (Ministry of Finance of the Czech Republic 2017a). 2017 februárjától kezdve léptek életbe a hatásosabb fiskális szabályokat és intézményeket létrehozó törvények és rendeletek, melyekben bevezetésre kerültek az 1. ábrán szemléltetett szabályok.

A kiadási szabály szerint az államháztartás teljes kiadása nem haladhatja meg a következő értéket: az államháztartás konszolidált bevételének elörejelzett értéke csökkentve az üzleti ciklus bevételre gyakorolt hatásával és az egyszeri vagy egyéb átmeneti intézkedések értékével, plusz a várható nominális GDP egy százaléka. A közszféra teljes kiadásainak összegét egy korrekciós komponens csökkenti, amennyiben az adott évben a kiadások értéke meghaladja az előző évi nominális GDP 2 százalékát.

1. ábra A költségvetés felelősségi szabályainak négy pillére Csehországban

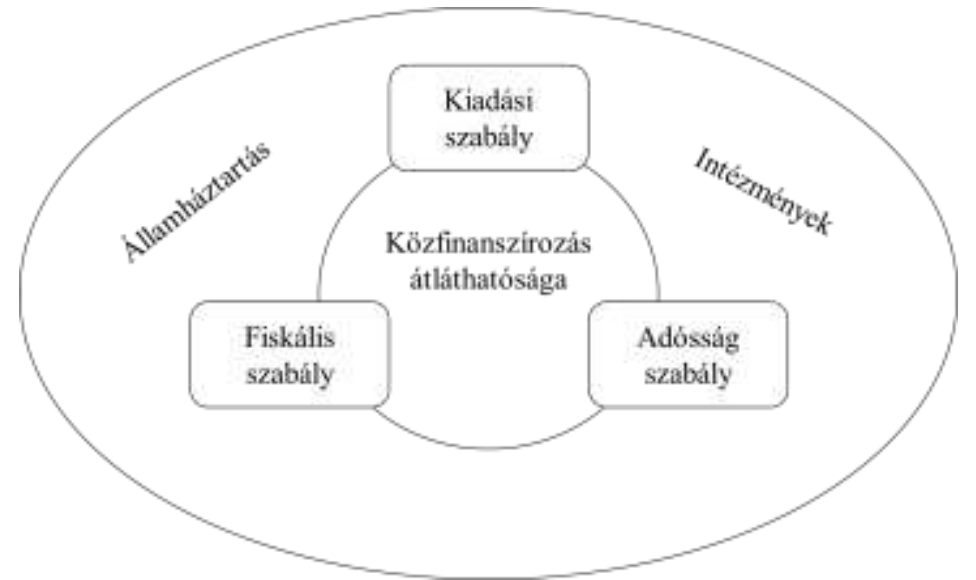

Forrás: Ministry of Finance of the Czech Republic (2017b) alapján saját szerkesztés 
Az adósságszabály szerint, ha az államadósság meghaladja a nominális GDP 55\%-át, akkor a hosszú távú fenntarthatóság érdekében alkalmazni kell bizonyos intézkedéseket az államháztartás alrendszereinek. Ezen intézkedések közé tartozik, hogy az önkormányzatok és a régiók következő évre vonatkozó költségvetésének kiegyensúlyozottnak vagy többlettel rendelkezőnek kell lennie. A költségvetés hiánnyal is jóváhagyható, ha az Európai Uniótól származó elö- vagy társfinanszírozás miatt keletkezett. Mentesítő záradék is van a törvényhez kapcsolva, mely szerint, ha a gazdasági fejlődés jelentősen visszaesik (azaz a negyedéves szezonálisan kiigazított GDP csökkenés minimum 2 százalék vagy az utolsó negyedévben minimum 3 százalék a visszaesés az előző év azonos időszakához képest), továbbá, ha vészhelyzet, háború, természeti katasztrófák következményeinek megszüntetésére irányuló kiadások elérik a GDP 3 százalékát. Ha a GDP arányos államadósság eléri a 60 százalékos értéket, akkor az adott időszaki államadósság és a 60 százalékos határ közötti eltérést minimum 5 százalékkal és a strukturális egyenleget évi 0,5 százalékponttal kell csökkentenie a kormányzatnak évente.

Az önkormányzatokra vonatkozó fiskális szabály értelmében az adósságuk összege a mérlegfordulónapon nem haladhatja meg a utolsó négy pénzügyi évben elért átlagos jövedelem 60 százalékát. Ha meghaladja, akkor a küszöb és a tényleges érték közötti különbséget legalább 5 százalékkal kell csökkenteni. Amennyiben az önkormányzat nem csökkenti az adósságát, akkor a minisztérium döntése alapján a következő naptári évben felfüggesztheti az adóbevételek folyósítását. Ez a felfüggesztés mindaddig tart, amíg az adósság a 60 százalékos érték alá nem csökken vagy az adott önkormányzat kéri, hogy folyósítsák az összegeket az adósságvisszafizetés érdekében. A transzparencia erősítése érdekében a pénzügyminisztérium létrehozott egy információs portált ${ }^{1}$ is, amely lehetővé teszi a kormányzatról és az önkormányzatokról szóló költségvetési és számviteli információkhoz való hozzáférést.

2018-tól kezdte meg működését a National Budget Council². A költségvetési tanács az Európai Uniós törekvésekkel összhangban bevezetett nemzeti költségvetési menedzsment reform részeként jött létre a 23/2017 Költségvetési felelősségről szóló törvény keretében. A három főből álló független szakértői testület elsődleges feladata az állami és egyéb államhoz közeli intézmények 23/2017-es törvénynek való megfelelésének értékelése. A költségvetési tanács által kiadott vélemények és jelentések iránymutatóként szolgálnak a kormány, a képviselőház és a helyi és regionális önkormányzatok költségvetési politikájának felelösségteljes tervezésében és végrehajtásában. A költségvetési tanács a nagyközönség számára is hasznos ismereteket közöl, hogy minden állampolgár megérthesse az államháztartás állapotát és fejlődésének irányát. Továbbá fontos feladata az államháztartás hosszú távú fenntarthatóságáról szóló jelentés elkészítése és a Parlament felé történő benyújtása, melyben a gazdasági és társadalmi fejlődés, foglalkoztatás és a nemzedékek közötti kohézió állapotára is kitér (UNNR 2018).

\footnotetext{
${ }^{1}$ Az információs portál a monitor.mfcr.cz weboldalon érhető el.

2 (ahogyan magukat honlapjukon nevezik (UNRR 2018), az OECD adatbázisában Czech Fiscal Council néven lehet megtalálni az intézményt (OECD 2018))
} 


\section{Lengyelország fiskális keretrendszere}

Lengyelország Csehországhoz hasonlóan kis államadóssággal rendelkezett a rendszerváltozás idején, de a fiskális szabályok bevezetését már 1997-ben megkezdték. Az adósságra vonatkozó szabályt alkotmányban rögzítették, mely szerint az adósság (nemzeti módszertan szerint számolva) nem haladhatja meg a GDP hatvan százalékát. Ezt a szabályt kiegészítették egy védősávokról szóló rendelkezéssel (az államháztartásról szóló törvény kereteiben), amely egy 50\%-os és egy 55\%-os védősávval támogatja a $60 \%$-os küszöböt. A második védősáv átlépésekor szigorodnak a szabályok, a költségvetési törvénynek biztosítani kell, hogy a két évvel későbbi költségvetés nem lesz deficites. A költségvetési egységek kiadásai közül csak az EU által finanszírozott kiadások haladhatják meg a bevételeket. Az állami bérek és költségvetési kölcsönnyújtás befagyasztására, a nyugdíjak csak inflációs indexálására kerül sor (a 20\%-os reálbérsúlyt nem veszik figyelembe), a kormány konszolidációs programjában a hosszú távú kiadási programokat és külföldi hitelböl megvalósuló projekteket is részletesen áttekintik. A 60\%-os küszöb átlépése esetén az állami garanciavállalást is betiltják és a kormányzati egységek kiadásai nem haladhatják meg bevételeiket, a konszolidációs programban konkrét adósság csökkentő intézkedéseket fogalmaznak meg (Ódor-P. Kiss 2011). Az államháztartási reform részeként 2007 júniusában elfogadták az Államháztartási törvényt. A legfontosabb fiskális szabályok és szabályszerü költségvetés tervezés az Alkotmányban lettek rögzítve (Republic of Poland 2007).

A gazdasági válság hatására 2008-ban az államháztartási hiány 3,6 százalékra növekedett. Ennek hátterében a GDP arányos bevételek csökkenése, a nyugdíjjárulékok és a GDP csökkenése, valamint a kiadások GDP arányos emelkedése (leginkább a beruházási és foglalkoztatással kapcsolatos kiadásoké) voltak. (Republic of Poland 2010). 2009-ben a hiány tovább növekedett, 7,3 százalékra, 2010-ben pedig 7,9 százalék volt. A számos egyensúlytalanságot okozó tényező közül a személyi jövedelem és társasági adó bevételek csökkenése, az alacsonyabb járulékbefizetés növekedése emelhető ki. Annak ellenére, hogy a kiadások csökkentek, az államadósság 2010-ben 55,1 százalékos értékével elérte a második biztonsági sávot. A folyamatok megfékezése érdekében végrehajtott kiadáskonszolidáció hozzájárult a költségvetési alapok legitimitásának javításához és hatékonyságának növekedéséhez. Az ideiglenes kiadási szabály bevezetése is pozitívan hatott a kiadásokra (Republic of Poland 2011).

Az államadósság szabály 2011 elejétől megváltozott, a két biztonsági küszöb emelkedett, 55 és 60 százalékra (a nemzeti módszertan szerint számolva, ami eltér az ESA módszertanától) (Republic of Poland 2012). Az adósságszabályon túl bevezetésre került az új kiadási szabály az államháztartási törvény kereteiben. A szabály értelmében az éves reálnövekedés csak egy százalék lehet a költségvetési kiadások diszkrecionális körében. A kamatkiadások, az EU-befizetés, útépítés és fenntartás, hosszú távú projektek, EU-finanszírozású projektek és védelmi kiadások mind a diszkrecionális körön kívüli tételek (Ódor-P. Kiss 2011). A szabályozással a kiadásokat sikerült kordában tartani. 
A gyengülő hazai kereslet, a külkereskedelmi hiány emelkedése, az alacsony infláció és az adóbevételek pro-ciklikus természete miatt a fiskális konszolidáció 2013-ban lassult, a deficit ismét emelkedésnek indult, a GDP 4,3 százalékát tette ki. A gazdasági növekedés további gyengülése az ÁFA és társasági adó bevételekre is negatív hatást gyakorolt. A bruttó államadósság a GDP 57,1 százalékát tette ki. Mivel az államadósság átlépte az 50 százalékos határt, ezért a stabilizációs kiadási szabály lépett életbe az átmeneti kiadási szabály helyett (Republic of Poland 2014). A 2014 től érvénybe lévő nyugdíjreform a GDP 0,4 százalékával emelte meg az államháztartási hiányt, de a 3,2 százalékos értékével még mindig csökkent az előző évhez képest. A GDP növekedés az ÁFA bevételeken keresztül segítette a költségvetés konszolidációját. A bruttó államadósság GDP arányos értéke 50,1 százalékra csökkent. A kiadási szabály 50 és 55 százalékos küszöbértékeit 7 százalékponttal csökkentették a 2014 májusi államháztartási törvény módosításával, annak érdekében, hogy az államadósság egy alacsonyabb szinten stabilizálódjon és a lengyel fiskális politika hitelessége is javuljon (Republic of Poland 2015).

1. táblázat Jelenleg érvényes fiskális szabályok Lengyelországban

\begin{tabular}{|c|c|c|c|c|}
\hline Szabály & Adósságkorlát & Hiánykorlát & Kiadási korlát & Adósságkorlát \\
\hline Szektor & Államháztartás & Helyi önkormányzatok & Államháztartás & $\begin{array}{l}\text { Helyi } \\
\text { önkormányzatok }\end{array}$ \\
\hline Mutató & $\begin{array}{l}\text { GDP arányos } \\
\text { államadósság }\end{array}$ & $\begin{array}{l}\text { Nominális költségvetési } \\
\text { egyenleg }\end{array}$ & $\begin{array}{l}\text { Nominális kiadás } \\
\text { növekedés }\end{array}$ & $\begin{array}{l}\text { Adósságszolgálat } \\
\text { rátája }\end{array}$ \\
\hline Definíció & $\begin{array}{l}\text { Az államadósság nem } \\
\text { haladhatja meg a GDP } \\
60 \text { százalékát. }\end{array}$ & $\begin{array}{l}\text { A helyi önkormányzatok } \\
\text { tervezett folyó kiadásai nem } \\
\text { haladhatják meg a tervezett } \\
\text { folyó bevételeket. Kivétel az } \\
\text { EU-s és EFTA által még } \\
\text { nem folyósított kiadások. }\end{array}$ & $\begin{array}{l}\text { A kiadások } \\
\text { növekedése nem } \\
\text { haladhatja meg a } \\
\text { középtávú GDP- } \\
\text { növekedést, kivéve, } \\
\text { ha a korrekciós } \\
\text { mechanizmus } \\
\text { megindult. }\end{array}$ & $\begin{array}{l}\text { Az adott pénzügyi } \\
\text { évben fizetendő } \\
\text { kiadások nem } \\
\text { haladhatják meg a } \\
\text { bevételeket. }\end{array}$ \\
\hline $\begin{array}{l}\text { Jogszabályi } \\
\text { alap }\end{array}$ & $\begin{array}{l}\text { Alaptörvény, } \\
\text { Stabilitási törvény }\end{array}$ & $\begin{array}{l}\text { Alkotmány vagy törvénynél } \\
\text { magasabb jogszabály }\end{array}$ & Törvény & $\begin{array}{l}\text { Alkotmány vagy } \\
\text { törvénynél } \\
\text { magasabb } \\
\text { jogszabály }\end{array}$ \\
\hline $\begin{array}{l}\text { A folyamatokat } \\
\text { figyelemmel } \\
\text { kísérö testület }\end{array}$ & $\begin{array}{l}\text { Állami számvevőszék, } \\
\text { Parlament, } \\
\text { Pénzügyminiszter, } \\
\text { Független testület }\end{array}$ & $\begin{array}{l}\text { Állami számvevőszék, } \\
\text { Parlament }\end{array}$ & $\begin{array}{l}\text { Pénzügyminiszter, } \\
\text { Parlament, } \\
\text { Független testület }\end{array}$ & $\begin{array}{l}\text { Kormányzati } \\
\text { struktúra }\end{array}$ \\
\hline $\begin{array}{l}\text { A céltól való } \\
\text { eltérést } \\
\text { megállapító } \\
\text { szervezet }\end{array}$ & $\begin{array}{l}\text { Parlament, Független } \\
\text { testület }\end{array}$ & Parlament & Független testület & Parlament \\
\hline $\begin{array}{l}\text { Nem } \\
\text { megfelelőségi } \\
\text { intézkedés }\end{array}$ & $\begin{array}{l}\text { A korrekciós } \\
\text { mechanizmus } \\
\text { automatikusan } \\
\text { bekapcsolódik. } \\
\text { Vannak előre } \\
\text { meghatározott } \\
\text { következmények. }\end{array}$ & $\begin{array}{l}\text { Nincs előre meghatározott } \\
\text { intézkedés }\end{array}$ & $\begin{array}{l}\text { Nincs elöre } \\
\text { meghatározott } \\
\text { intézkedés }\end{array}$ & $\begin{array}{l}\text { Nincs elöre } \\
\text { meghatározott } \\
\text { intézkedés }\end{array}$ \\
\hline Hatályos & $2014-$ & 2015- & 2014- & 2016- \\
\hline
\end{tabular}

Forrás: Európai Bizottság (2017) alapján saját szerkesztés 
Az elsőként meghozott adósságszabály a nominális államadósság GDP arányos értékére vonatkozott és az állami számvevőszék és a pénzügyminiszter felügyeletére bízott szabály 2013-ig volt érvényben. 2014-ben került bevezetésre a jelenlegi adósságszabály, melynek definíciója nem változott a korábbihoz képest, csak a szabályt felügyelök és a szabály megsértése esetén alkalmazott intézkedések változtak (1. táblázat).

\section{Magyarország fiskális keretrendszere}

Magyarországon az első fiskális szabályt 1996-ban vezették be és 2011-ig volt érvényben, ez egy a helyi önkormányzatok adósságára vonatkozó korlát volt, amely meghatározta, hogy a helyi önkormányzat kötelezettségvállalásainak (kölcsönfelvétel és kapcsolódó költségek, kötvénykibocsátás stb.) éves felső határa az adósság visszafizetésére való képességgel arányos mértékü lehet. Ezt követte a 2007-ben bevezetett hiánykorlát, mely csak egy évig müködött, utána 2009-től adósságkorlát került bevezetésre. A központi kormányzatra és a szociális védelemre vonatkozóan az elsődleges egyenleg nominális értékére és a reál államadósság százalékos változására vonatkozott a szabály, az ellenőrzésével független testület volt megbízva és elöre nem meghatározott intézkedések kerültek volna bevezetésre a szabály megsértése esetén (Európai Bizottság 2017). A „plafontörvény” bevezetése kényszerüség mintsem választás volt, az államadósság növekedésének próbált ily módon gátat szabni a fiskális politika. A többi visegrádi országban nem kellett ekkora mértékü államadóssággal küzdeni, ezért is lehet, hogy például Csehországban csak 2017-től kerültek bevezetésre fiskális szabályok.

A ,plafontörvény” felhatalmazásával az első költségvetési tanács 2008-ban kezdte meg müködését. Egy olyan jelentős háttérszervezet kialakítására lehetőséget kapó intézmény volt, amely közjogi szerepet töltött be (csak Hollandiában és Németországban van hasonló intézmény), ugyanakkor sem szankcionálási, sem közvetlen beavatkozási lehetősége nem volt, csak a meggyőzés eszközével élhetett (Kovács 2016a, Kopits-Romhányi 2010). A törvénykezésben fordulópontot jelentett a 2010-es választás, amely után a kormányzat 2/3-os többséggel rendelkezett. 2011től elvették az elemző apparátust a költségvetési tanácstól és müködési és eljárási szabályait is módosították. Az új KT közjogi szerepe továbbra is megmaradt, véleménynyilvánítási és javaslattételi jogkört kapott (Kovács 2016a).

2014-ben átalakították az adósságszabályt, jelenleg érvényes formájáról 2015-ben döntöttek. A hiánykorlát 2013-tól ismét bevezetésre került először a nominális, majd a strukturális egyenlegre vonatkozóan. A jelenleg hatályos fiskális szabályok jellemzőit tartalmazza a 2. táblázat (Európai Bizottság 2017). 
2. táblázat Jelenleg érvényes fiskális szabályok Magyarországon

\begin{tabular}{|c|c|c|c|}
\hline Szabály & Adósságkorlát & Hiánykorlát & Hiánykorlát \\
\hline Szektor & Államháztartás & Államháztartás & Államháztartás \\
\hline Mutató & $\begin{array}{l}\text { GDP arányos } \\
\text { államadósság }\end{array}$ & $\begin{array}{l}\text { Nominális egyenleg a } \\
\text { GDP százalékában }\end{array}$ & $\begin{array}{l}\text { Strukturális egyenleg a } \\
\text { GDP százalékában }\end{array}$ \\
\hline Definíció & $\begin{array}{l}\text { Mindaddig, amíg az } \\
\text { államadósság meghaladja } \\
\text { GDP felét, az } \\
\text { Országgyúlés csak olyan } \\
\text { költségvetési törvényt } \\
\text { fogadhat el, amely az } \\
\text { államadósság GDP } \\
\text { arányos csökkentését } \\
\text { tartalmazza. }\end{array}$ & $\begin{array}{l}\text { Az államháztartás hiánya } \\
\text { nem haladhatja meg a } \\
\text { GDP } 3 \text { százalékát* }\end{array}$ & $\begin{array}{l}\text { Az államháztartási } \\
\text { egyensúlyt olyan szintre } \\
\text { kell beállítani, amely } \\
\text { lehetővé teszi a } \\
\text { középtávú költségvetési } \\
\text { célkitüzés elérését. }\end{array}$ \\
\hline Jogszabályi alap & $\begin{array}{l}\text { Alaptörvény, } \\
\text { Stabilizációs törvény }\end{array}$ & Államháztartási törvény & Törvény \\
\hline $\begin{array}{l}\text { A folyamatokat } \\
\text { figyelemmel kísérő } \\
\text { testület }\end{array}$ & Független testület & $\begin{array}{l}\text { Pénzügyminiszter, } \\
\text { Állami számvevőszék, } \\
\text { Független testület }\end{array}$ & $\begin{array}{l}\text { Pénzügyminiszter, } \\
\text { Állami számvevőszék }\end{array}$ \\
\hline $\begin{array}{l}\text { A céltól való eltérést } \\
\text { megállapító szervezet }\end{array}$ & $\begin{array}{l}\text { Pénzügyminiszter és } \\
\text { független testület }\end{array}$ & $\begin{array}{l}\text { Pénzügyminiszter, } \\
\text { Állami számvevöszék, } \\
\text { Független testület }\end{array}$ & Független testület \\
\hline $\begin{array}{l}\text { Nem megfelelőségi } \\
\text { intézkedés }\end{array}$ & $\begin{array}{l}\text { A korrekciós } \\
\text { mechanizmus } \\
\text { automatikusan } \\
\text { bekapcsolódik }\end{array}$ & $\begin{array}{l}\text { Nincs előre } \\
\text { meghatározott intézkedés }\end{array}$ & $\begin{array}{l}\text { Nincs előre } \\
\text { meghatározott intézkedés }\end{array}$ \\
\hline Hatályos & $2015-$ & 2013- & 2014- \\
\hline
\end{tabular}

Megjegyzés: * Lényeges a kiegészítés, hogy különbséget kell tenni a pénzforgalmi hiánytól, amelyre nem vonatkozik közvetlen előírás, csak közvetett, az államadósság-szabályon keresztül.

Forrás: Európai Bizottság (2017) alapján saját szerkesztés

Az államadósságra vonatkozó szabály az Alaptörvényben van rögzítve és a következőképpen került megfogalmazásra: „(4) Az Országgyülés nem fogadhat el olyan központi költségvetésről szóló törvényt, amelynek eredményeképpen az államadósság meghaladná a teljes hazai össztermék felét.

(5) Mindaddig, amíg az államadósság a teljes hazai össztermék felét meghaladja, az Országgyülés csak olyan központi költségvetésröl szóló törvényt fogadhat el, amely az államadósság a teljes hazai össztermékhez viszonyitott arányának csökkentését tartalmazza.

(6) A (4) és (5) bekezdésben foglaltaktól csak különleges jogrend idején, az azt kiváltó körülmények okozta következmények enyhitéséhez szükséges mértékben, vagy a nemzetgazdaság tartós és jelentös visszaesése esetén, a nemzetgazdasági egyensúly helyreállitásához szükséges mértékben lehet eltérni” (Magyarország Alaptörvénye 2011).

Az Alaptörvény rendelkezését egészíti ki a Stabilitási törvény ún. vétójogra vonatkozó 24., 25. és 25/A. paragrafusa. A vétójog alkalmazásának lehetőségére egy alkalommal kerülhetett volna sor, amikor a 2013-as költségvetés tervezetének 
véleményezésekor a KT a hiánycélt kifogásolta, a makropálya megalapozottságát elutasította és újat kért. Az új előterjesztésben már a módosított makropálya, hiánycél és további egyensúlyt javító bevételi és kiadási intézkedések szerepeltek így nem volt szükség a vétójogra (Kovács 2016b).

A magyar fiskális keretrendszer az egyik legszigorúbb szabályrendszer az unióban, amely a magas államadósság elleni küzdelem következményeként alakult ki, gyakorlatilag kényszerpályára került a döntéshozás az államadósság megfékezése miatt. Az államadósságra vonatkozó adatsorokból az látszik, hogy 2012 óta csökken az államadósság, ami a jól megalkotott fiskális keretrendszer következményének is tekinthető. Bár a jelenlegi rendszer még nincs kipróbálva kifeszültebb gazdasági körülmények között, felmerülhet a kérdés, hogy lehet azért nincsenek ilyen körülmények, mert a rendszer jól müködik? Erre a kérdésre csak a jövőbeli kutatások tudnak majd választ adni.

\section{Szlovákia fiskális keretrendszere}

Szlovákia fiskális keretrendszere hasonlóan kiterjedté vált az elmúlt években (3. táblázat), mint Lengyelországé vagy Magyarországé. A szlovák kormányzat 2002-ben kezdte a fiskális szabályok bevezetését. A helyi önkormányzatokra vonatkozó adósság és hiánykorlát bevezetésével, amelyek közül az előbbi még érvényben van, utóbbi változatlan formában 2004-ig volt hatályos, majd 2009-től módosított formában ismét a fiskális keretrendszer részét képzi. A helyi önkormányzatokra vonatkozó szabály szerint két korlátnak kell megfelelni, egyrészt a teljes adósság nominálisan nem haladhatja meg a jelenlegi költségvetési bevétel $60 \%$-át (a tőkejövedelmek és a pénzügyi tranzakciókból származó bevételek nélkül); másrészt az adósságok visszafizetésének éves részletei nem haladhatják meg az előző költségvetési év bevételeinek 25\%-át nominális értékben. A helyi önkormányzatok kiadási szabálya, mindezt azzal egészíti ki, hogy az önkormányzatok költségvetésének kiegyensúlyozottnak vagy többlettel rendelkezőnek kell lenniük. A tőkemérleg mutathat hiányt, feltéve, hogy ezt a hiányt az előző évekből átutalt önkormányzatok el nem költött pénzeszközei, kölcsönök vagy a folyó költségvetés többletéből finanszírozzák az adott pénzügyi évben (Európai Bizottság 2017).

Az államháztartásra vonatkozó adósságszabály 2012-ben került bevezetésre, ezt követte a hiánykorlát 2014-ben és a kiadási korlát 2016-ban. A hatályos adósságszabály szerint az alkotmányos költségvetési felelősségről szóló törvény meghatározza az államháztartás bruttó adósságának küszöbét. A végső küszöbérték túllépése esetén a Parlament bizalmi szavazást kezdeményez. 4 küszöbintervallum van: 50-53\%, 53-55\%, 55-57\% és 57-60\%. A legmagasabb adósságküszöb a 2017 ig a GDP 60\%-a volt, azt követően minden adósságintervallum évente egy százalékponttal csökken, amíg a legmagasabb adósságráta 2027-re el nem éri a GDP 50\%-át. 2018-ban a felső küszöb a GDP 59\%-a, a második küszöb a GDP 56\%-a, és így tovább. Az egyes küszöbökhöz tartozó szankciók a következőképpen kerülnek bevezetésre. A szankcionálási mechanizmusok első szakasza lehetővé teszi a kormányzat számára az adósságszint csökkentésére irányuló saját intézkedéseket. Ha ezek nem elegendőek, és az adósság eléri a felső küszöb alatti GDP 5 százalékának 
megfelelő értéket, akkor a költségvetésre vonatkozó szigorúbb szabályok lépnek életbe, föleg a kiadási oldalon. Mivel ebben az esetben a cél az államháztartás adósságának stabilizálása, ezért ebben a szakaszban már az önkormányzatokra is vonatkoznak a szankciók (CBR 2013).

\section{3. táblázat Jelenleg érvényes fiskális szabályok Szlovákiában}

\begin{tabular}{|c|c|c|c|c|c|}
\hline Szabály & Adósságkorlát & Hiánykorlát & Adósságkorlát & Hiánykorlát & Kiadási korlát \\
\hline Szektor & $\begin{array}{l}\text { Helyi } \\
\text { önkormányzatok }\end{array}$ & $\begin{array}{l}\text { Helyi } \\
\text { önkormányzatok }\end{array}$ & Államháztartás & Államháztartás & $\begin{array}{l}\text { Központi } \\
\text { kormányzat }\end{array}$ \\
\hline Mutató & $\begin{array}{l}\text { Az adósságplafon } \\
\text { és a felső korlát a } \\
\text { visszafizetésekre, } \\
\text { az elöző } \\
\text { költségvetési évben } \\
\text { a bevétel } \\
\text { százalékában, } \\
\text { nominális értékben }\end{array}$ & $\begin{array}{l}\text { Nominális } \\
\text { költségvetési } \\
\text { egyenleg }\end{array}$ & $\begin{array}{l}\text { GDP arányos } \\
\text { államadósság }\end{array}$ & $\begin{array}{l}\text { Strukturális } \\
\text { egyenleg a GDP } \\
\text { százalékában }\end{array}$ & $\begin{array}{l}\text { Nominális kiadási } \\
\text { plafon az összes } \\
\text { kiadás } \\
\text { százalékában }\end{array}$ \\
\hline Definíció & $\begin{array}{l}\text { A helyi és } \\
\text { regionális } \\
\text { önkormányzatok } \\
\text { hitelfelvételi } \\
\text { limitjei vannak. }\end{array}$ & $\begin{array}{l}\text { Az önkormányzatok } \\
\text { költségvetésének } \\
\text { kiegyensúlyozottnak } \\
\text { vagy többlettel } \\
\text { rendelkezőnek kell } \\
\text { lenniük. }\end{array}$ & $\begin{array}{l}\text { A bruttó } \\
\text { államadósság nem } \\
\text { haladhatja meg a } \\
\text { speciális } \\
\text { küszöbértékeket. }\end{array}$ & $\begin{array}{l}\text { Az államháztartás } \\
\text { strukturális hiánya } \\
\text { egyenlő vagy } \\
\text { alacsonyabb, mint a } \\
\text { GDP } 0,5 \% \text {-a. }\end{array}$ & $\begin{array}{l}\text { Az államháztartási } \\
\text { törvényben nem } \\
\text { szereplő kiadásokat } \\
\text { acsak akkor lehet } \\
\text { végrehajtani, ha } \\
\text { azok teljes összege } \\
\text { nem haladja meg a } \\
\text { költségvetési } \\
\text { törvényben } \\
\text { jóváhagyott összes } \\
\text { kiadás } 1 \% \text {-át, és a } \\
\text { hiányt nem növelik. }\end{array}$ \\
\hline $\begin{array}{l}\text { Jogszabályi } \\
\text { alap }\end{array}$ & Törvény & Törvény & $\begin{array}{l}\text { Alkotmány vagy } \\
\text { törvénynél } \\
\text { magasabb } \\
\text { jogszabály }\end{array}$ & Törvény & Törvény \\
\hline $\begin{array}{l}\text { A } \\
\text { folyamatokat } \\
\text { figyelemmel } \\
\text { kísérő testület }\end{array}$ & $\begin{array}{l}\text { Pénzügyminiszter, } \\
\text { Független testület }\end{array}$ & $\begin{array}{l}\text { Pénzügyminiszter, } \\
\text { Független testület }\end{array}$ & $\begin{array}{l}\text { Pénzügyminiszter, } \\
\text { Független testület }\end{array}$ & $\begin{array}{l}\text { Pénzügyminiszter, } \\
\text { Független testület }\end{array}$ & $\begin{array}{l}\text { Pénzügyminiszter, } \\
\text { Független testület }\end{array}$ \\
\hline $\begin{array}{l}\text { A céltól való } \\
\text { eltérést } \\
\text { megállapító } \\
\text { szervezet }\end{array}$ & Pénzügyminiszter & Pénzügyminiszter & Pénzügyminiszter & $\begin{array}{l}\text { Pénzügyminiszter, } \\
\text { Független testület }\end{array}$ & $\begin{array}{l}\text { Pénzügyminiszter, } \\
\text { Független testület }\end{array}$ \\
\hline $\begin{array}{l}\text { Nem } \\
\text { megfelelőségi } \\
\text { intézkedés }\end{array}$ & $\begin{array}{l}\text { A korrekciós } \\
\text { mechanizmus } \\
\text { automatikusan } \\
\text { bekapcsolódik. }\end{array}$ & $\begin{array}{l}\text { A korrekciós } \\
\text { mechanizmus } \\
\text { automatikusan } \\
\text { bekapcsolódik }\end{array}$ & $\begin{array}{l}\text { A korrekciós } \\
\text { mechanizmus } \\
\text { automatikusan } \\
\text { bekapcsolódik. } \\
\text { Vannak előre } \\
\text { meghatározott } \\
\text { következmények. }\end{array}$ & $\begin{array}{l}\text { A korrekciós } \\
\text { mechanizmus } \\
\text { automatikusan } \\
\text { bekapcsolódik }\end{array}$ & $\begin{array}{l}\text { A korrekciós } \\
\text { mechanizmus } \\
\text { automatikusan } \\
\text { bekapcsolódik }\end{array}$ \\
\hline Hatályos & $2002-$ & 2009- & $2012-$ & 2014- & 2016- \\
\hline
\end{tabular}

Forrás: Európai Bizottság (2017) alapján saját szerkesztés 
Beépítésre került egy mentesítő záradék, amely olyan eseteket sorol fel, amikor felmentés jár a szankciók alól. Ilyen helyzet a háborús időszak alatt vagy a választási utáni első két évben nem kell alkalmazni azokat a szankciókat, amelyek a felső adósságkorlátnál lépnének életbe. Az utóbbi kivétel célja, hogy az új kormánynak ne kelljen a korábbi határozatok miatt bünhődnie. A szankciók kivételesen heves és hirtelen recesszió esetén alkalmazhatók, de csak átmenetileg, 36 hónapon keresztül, ezen kívül, ha a közkiadások a természeti katasztrófák, a bankszektor feltőkésítésének vagy a nemzetközi szerződésekből eredő kötelezettségek teljesítésének biztosítására szolgálnak és összegük ugyanazon éven belül eléri a GDP 3\%-át (CBR 2013).

$\mathrm{Az}$ államháztartásra vonatkozó hiánykorlát szerint, alapvetően az államháztartás strukturális hiánya maximum a GDP 0,5 százaléka lehet. Ha az államadósság jelentősen alacsonyabb, mint a GDP 60 százaléka és a hosszú távú fenntarthatósági kockázatok alacsonyak, akkor a strukturális deficit nem haladhatja meg a GDP egy százalékát (Európai Bizottság 2017).

A szabályrendszer müködésének hatékonyságát segítő, ellenőrző szervet, költségvetési tanácsot (Council for Budget Responsibility, röviden CBR) is létre hoztak, közjogi besorolását tekintve független szervként müködik. A fiskális felelősségről szóló 493/2011 számú törvény szerint a CBR négy kiemelt területtel foglalkozik, melyek közül az első az államháztartás hosszú távú fenntarthatóságáról szóló jelentés elkészítése. A második a beszámoló készítése a Parlament számára a költségvetési felelősség és a költségvetési átláthatóság szabályainak való megfelelésröl. Továbbá véleményt készíthet a parlamenthez benyújtott jogalkotási javaslatokról és végül az államháztartás alakulásának nyomon követésével és értékelésével kapcsolatos egyéb tevékenységet is végez, például tájékoztatást nyújt a potenciális kockázatokról, alternatív forgatókönyvet mutat be vagy módszertant fejleszt az államháztartás vizsgálatához használható mutatókhoz (Európai Bizottság 2017).

A fiskális keretrendszert erősítendő, az államháztartásra és a helyi önkormányzatokra vonatkozó szabályokat 2016-tól kiegészítették a központi költségvetésre vonatkozó kiadási korláttal, mely szerint az államháztartási törvényben nem szereplő kiadásokat csak akkor lehet végrehajtani, ha azok teljes összege nem haladja meg a költségvetési törvényben jóváhagyott összes kiadás 1\%-át, és nem növelik a hiányt. A törvény lehetővé teszi a kiadások növekedését a ,jó idők”-ben, kezdetben a szabály 15\%-os határt szabott meg (Európai Bizottság 2017).

\section{A keretrendszerek értékelése az Európai Unió értékelési rendszere alapján}

A szabályok számán kívül, minőségbeli változás is tapasztalható az európai országok fiskális politikájában, ennek mérésére az Európai Bizottság létrehozta az úgynevezett fiskális szabályok indexét (Fiscal Rules Index) és a fiskális szabály erősségének indexét (Fiscal Rule Strength Index, röviden: FRSI). Utóbbi mutató számításakor Deroose et al. (2006) alapján a következő kritériumokat ${ }^{3}$ veszik figyelembe: jogalap,

\footnotetext{
${ }^{3}$ A kritérium rendszer pontos felépítését lásd 1. melléklet.
} 
kötelező jelleg, megfelelést ellenőrző szervezetek, korrekciós mechanizmusok és sokkokkal szembeni ellenállóság. Az egyes szabályokhoz minden kritérium szerint egy értéket rendelnek, ezeket az értékeket összesítik, minden kritérium azonos súlyt kap. A kapott eredményt 0 és 1 skálára standardizálják, így minden szabálynak lesz egy index értéke. Majd ezt követően összegzésre kerülnek egy adott országra és adott időszakra vonatkozóan. A fiskális szabályok indexét úgy kapják meg, hogy az előbb számított fiskális szabály erősségének indexét megszorozzák az államháztartás adott szabállyal való lefedettségével, ezeket az értékeket összegezzük. Ha ugyanaz a szabály több államháztartási szintre is vonatkozik, akkor a szabály az, hogy a legmagasabb szinthez tartozó szabály súlya egy, míg a második és harmadik szabály $1 / 2$ és $1 / 3$ súlyt kap. Tehát a hozzárendelt súlyokat a fiskális szabály ereje és lefedettsége adja. Ezeket a súlyokat úgy alkalmazzák, hogy tükrözze az államháztartás ugyanazon szintjeire vonatkozó többszörös szabályok csökkenö határhasznát (Európai Bizottság 2017).

A visegrádi országokra vonatkozó fiskális szabályok indexének időbeli alakulását mutatja a 2. ábra, melyről leolvasható, hogy az országok mindegyike fejlesztette a fiskális szabályrendszerét. A szabályok minőségének javulása a 2007 2008-as válság után, 2012-től figyelhető meg leginkább. Az ábrán a negatív értéktartomány a szabályok hiányát jelzi.

2. ábra A fiskális szabályok indexének alakulása visegrádi országokban, 1990-2017

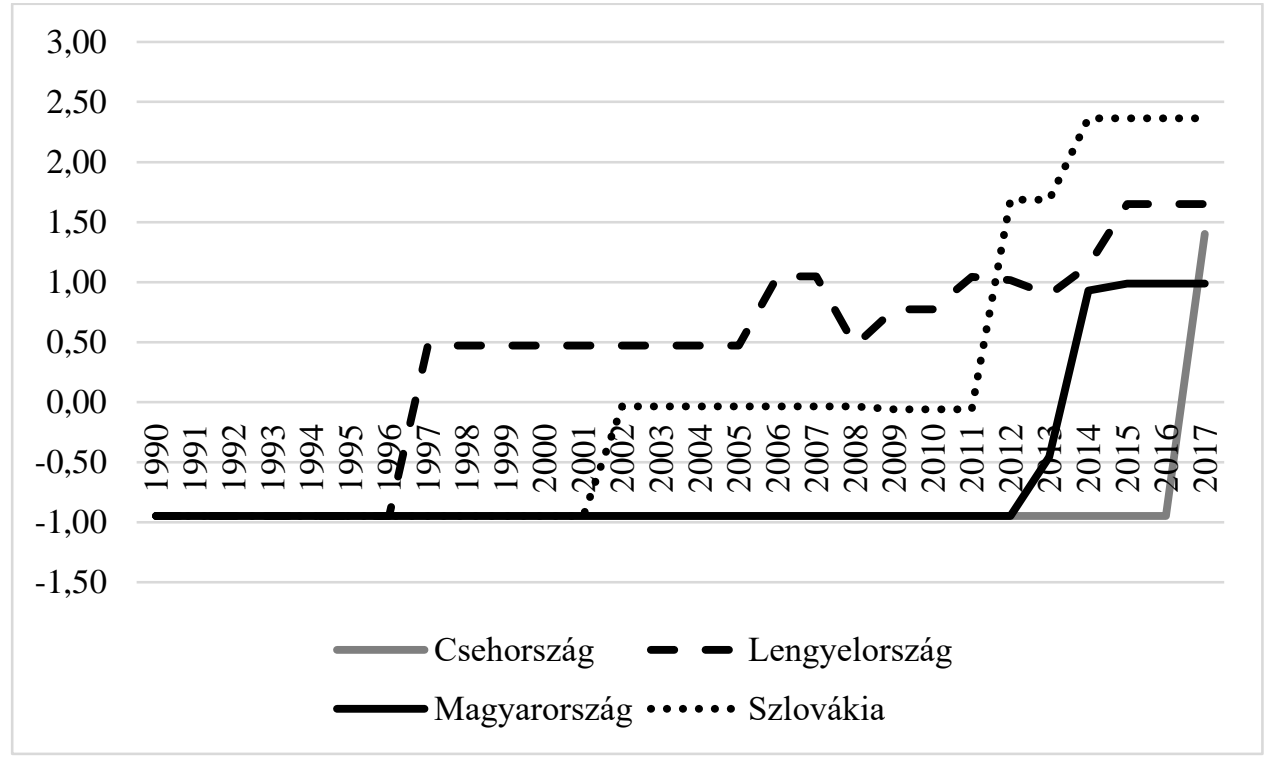

Forrás: Európai Bizottság (2018) alapján saját szerkesztés

Sajnos az adatsorok hossza miatt empirikus vizsgálatot nem tudtam végezni a fiskális szabályok és fiskális intézmények hatásáról, de egy szintézis kirajzolódik (4. táblázat). Megfigyelhető, hogy mindegyik országban van adósság szabály (ez EU tagként természetesnek mondható), és Lengyelország kivételével mindegyik 
országban van valamilyen mentesítő záradék is. Az egész államháztartásra vonatkozó kiadási szabály Csehországban és Lengyelországban müködik, míg Szlovákiában és Magyarországon hiányszabály van érvényben. Külön az önkormányzatokra vonatkozóan Lengyelország és Szlovákia hiányszabályt és adósságszabályt is alkalmaz, míg Csehországban csak adósságszabály van. Független fiskális intézmény Lengyelország kivételével mindegyik országban müködik.

4. táblázat A visegrádi országok fiskális keretrendszere (2018)

\begin{tabular}{lcccccc}
\hline & $\begin{array}{l}\text { Adósság- } \\
\text { szabály }\end{array}$ & $\begin{array}{l}\text { Hiány- } \\
\text { szabály }\end{array}$ & $\begin{array}{l}\text { Kiadási- } \\
\text { szabály }\end{array}$ & $\begin{array}{l}\text { Hiány- } \\
\text { szabály } \\
\text { (önkor- } \\
\text { mányzat) }\end{array}$ & $\begin{array}{l}\text { Adósság } \\
\text { (önkor- } \\
\text { mányzat) }\end{array}$ & FFI \\
\hline Csehország & $\mathrm{X}(\mathrm{m})$ & & $\mathrm{X}$ & & $\mathrm{X}$ & $\mathrm{X}$ \\
Lengyelország & $\mathrm{X}$ & $\mathrm{X}$ & $\mathrm{X}$ & $\mathrm{X}$ & \\
Magyarország & $\mathrm{X}(\mathrm{m})$ & $\mathrm{XX}$ & & & & $\mathrm{X}$ \\
Szlovákia & $\mathrm{X}(\mathrm{m})$ & $\mathrm{X}$ & & $\mathrm{X}$ & $\mathrm{X}$ & $\mathrm{X}$ \\
\hline
\end{tabular}

Megjegyzés: az X-ek a jelenleg érvényes szabályt mutatják, a (m) a mentesítő záradék létére utal. Forrás: saját szerkesztés

Fontos kiemelni, hogy Magyarország esetében a költségvetési tanács közjogi szerepe is hozzájárul a fiskális keretrendszer erősítéséhez. A keretrendszer fejlődését a korábbi években felhalmozott és fenntarthatatlansággal fenyegető államadósság szint indukálta Magyarországon. A többi visegrádi ország esetében az államadósságtól való félelem kevésbé ösztönözte a szabályok megalkotását, inkább a Stabilitási és Növekedési Egyezmény és módosításainak való megfelelés indukálta a szabályok bevezetését és fejlesztését.

\section{7. Összegzés}

A tanulmány kutatási kérdése arra kereste a választ, hogy mennyiben hasonlítanak egymásra a visegrádi országok fiskális keretrendszerei. A kutatás eredményei alapján megállapítható, hogy a visegrádi országok széles spektrumát alkalmazzák a fiskális szabályoknak, jellemzően legalább négy érvényben van napjainkban. Magyarország kivételével, ezek a szabályok nemcsak az államháztartás egészére, hanem az önkormányzatokra külön is kitérnek.

Ha a fiskális keretrendszer fejlődési pályáját tekintjük, akkor az látható, hogy a visegrádi országok bár az Európai Uniós kötelezettségeknek megfelelve, de nem közvetlenül a 2008-as válság következtében döntöttek a fiskális szabályok bevezetése mellett, hanem inkább gazdaságpolitikai elköteleződés (vagy kényszer Magyarország esetében) eredménye volt a fiskális keretrendszerük bevezetése és fokozatos bővítése. Ugyanakkor a fiskális szabályrendszer bővülésében szerepet játszott az államadósság válság miatt az EU-ban meghozott eurózónára kötelező (a többi ország számára opcionális) költségvetési szabályrendszer kiterjesztése. 


\section{Köszönetnyilvánítás}

A kutatást az EFOP-3.6.2-16-2017-00007 azonosító számú, Az intelligens, fenntartható és inkluziv társadalom fejlesztésének aspektusai: társadalmi, technológiai, innovációs hálózatok a foglalkoztatásban és a digitális gazdaságban címü projekt támogatta. A projekt az Európai Unió támogatásával, az Európai Szociális Alap és Magyarország költségvetése társfinanszírozásában valósul meg.

\section{Felhasznált irodalom}

CBR (2013): Report on compliance with the fiscal responsibility and budget transparency Rules for the year 2012 http://www.rozpoctovarada.sk/download2/Compliance_with_rules2013_FIN AL_EN_01.pdf Letöltve: 2018. október 13.

Deroose, S. - Moulin, L. - Wierts, P. (2006): National expenditure rules and expenditure outcomes: Evidence for EU Member States. Wirtschaftspolitische Blatter, 1, 27-42.

Európai Bizottság (2017): Fiscal rules database.

https://ec.europa.eu/info/publications/fiscal-rules-database_en Letöltve: 2018. szeptember 14.

Európai Bizottság (2018): Fiscal rules database. https://ec.europa.eu/info/sites/info/files/economyfinance/numerical_fiscal_rules_2017.xlsx Letöltve: 2019. szeptember 26.

Kopits, Gy. - Romhányi, B. (2010): A Költségvetési Tanács indulásának tanulságai. Közgazdasági Szemle, 57, 7-8, 573-590.

Kovács, Á. (2016a): A Költségvetési Tanács a magyar Alaptörvényben. Vázlat az intézményfejlődésről és az európai uniós gyakorlatról. Pénzügyi szemle, 61, 3, $320-337$.

Kovács, Á. (2016b): Szabályalapú költségvetés: út a költségvetési stabilitáshoz: A magyar megoldás. Polgári Szemle, 12, 4-6, https://polgariszemle.hu/aktualisszam/133-kozpenzugyek-gazdasagpolitika-fenntarthato-fejlodes/834szabalyalapu-koeltsegvetes-ut-a-koeltsegvetesi-stabilitashoz Letöltve: 2017. július 3 .

Ministry of Finance of the Czech Republic (2017a): Fiscal outlook of Czech Republic. https://www.mfcr.cz/en/statistics/fiscal-outlook/2017/fiscal-outlook-of-theczech-republic-nov-30160 Letöltve: 2018. július 4.

Ministry of Finance of the Czech Republic (2017b): Právní úprava rozpočtové odpovédnosti. https://www.mfcr.cz/assets/cs/media/Prezentace_201704_Rozpoctova-odpovednost.pdf Letöltve: 2018. július 4.

Ódor, L. - P. Kiss, G. (2011): Kivétel erősíti? Fiskális szabályok a visegrádi országokban. MNB-Szemle, 6, 2, 25-38.

OECD (2018): OECD Independent Fiscal Institutions Database. http://www.oecd.org/gov/budgeting/OECD-Independent-Fiscal-InstitutionsDatabase.xlsx Letöltve: 2018. október 23. 
Republic of Poland (2007): Convergence Programme 2007 Update. https://www.mf.gov.pl/en/c/document_library/get_file?uuid=27cb3355-45514ae5-b0b3-78dd2334f16e\&groupId=764034 Letöltve: 2018 . július 4.

Republic of Poland (2010): Convergence Programme 2009 Update. https://www.mf.gov.pl/en/c/document_library/get_file?uuid=136709ab-115e4f6b-9af2-53574e8abba4\&groupId=764034 Letöltve: 2018. július 4.

Republic of Poland (2011): Convergence Programme 2011 Update. https://www.mf.gov.pl/en/c/document_library/get_file?uuid=506b74c6-f2ba4926-91a4-162a43371204\&groupId=764034 Letöltve: 2018 . július 4.

Republic of Poland (2012): Convergence Programme 2012 Update. https://www.mf.gov.pl/en/c/document_library/get_file?uuid=5c32ee9e-15104334-b490-02a63c8b2700\&groupId=764034 Letöltve: 2018 . július 4.

Republic of Poland (2014): Convergence Programme 2014 Update. https://www.mf.gov.pl/en/c/document_library/get_file?uuid=0dbd467c-43774ddb-bfb3-404c194809bd\&groupId=764034 Letöltve: 2018 . július 4.

Republic of Poland (2015): Convergence Programme 2015 Update. https://www.mf.gov.pl/en/c/document_library/get_file?uuid=67efd434-74f548e5-9469-c28b71c6ecc3\&groupId=764034 Letöltve: 2018. július 4.

UNNR (2018): National Budget Council. https://unrr.cz/en/frequently-askedquestions-faqs/ Letöltve: 2018. október 23.

Yläoutinen, S. (2004): Fiscal frameworks in the Central and Eastern European Countries. Ministry of Finance. Finland Economics Department Discussion Paper, 72. 


\section{Melléklet}

1. melléklet A fiskális szabályok indexének kritérium rendszere

Kritériumok és értékelési szempontjaik

1. kritérium: A szabály jogszabálya vagy jogalapja (Statutory/legal base of the rule)

Alkotmányban rögzített.

Általános törvényben rögzített.

Koalíciós megállapodásban rögzített (beleértve a parlamentben megszavazott kormányprogramot vagy a kormányzati Elérhetö pont

alszektorok közötti nem törvényi megállapodást is)

Politikai kötelezettségvállalásban (központi kormányzat, helyi önkormányzat, pénzügyminiszter) vagy éves költségvetési törvényben rögzített.

\section{2. kritérium: A célok megállapítására vagy módosítására szolgáló lehetöség (Room for setting or revising objectives)}

A szabály célját, amit a létrehozó joganyag meghatároz, a kormány nem változtathatja meg vagy függesztheti fel ideiglenesen kivéve a jól-körülhatárolt helyzetekben (pl.: menekülési záradék).

A parlamenti jóváhagyás függvényében, a kormány átmenetileg megváltoztathatja a célt vagy dönthet a célról (ha a célok nincsenek definiálva a létrehozó joganyagban).

A kormány parlamenti jóváhagyás nélkül megváltoztathatja a célt.

3/a. kritérium: A szabály felügyeletéért felelös szervezet és korrekciós mechanizmus (Nature of the body in charge of rule monitoring and the correction mechanism)

Független szervezet által ellenőrzött (pl.: intézményi típusú költségvetési tanács).

Állami számvevőszék (ha nincs független költségvetési tanács) és/vagy parlament által ellenőrzött.

Pénzügyminisztérium vagy egyéb kormányzati szerv által ellenőrzött.

Nincs rendszeres ellenőrzés a szabály felett (nincs jelentés, amely rendszeresen értékeli a megvalósulást).

3/b. kritérium: Valós idejü ellenörzés (Real-time monitoring)

Valós idejü (negyedéves vagy gyakoribb) megfigyelés történik és a szabály jogalapja meghatározza a korrekciós intézkedéseket arra az esetre, ha a szabály tiszteletben tartásának veszélye felmerül a valós idejü mechanizmus révén.

Valós idejü (negyedéves vagy gyakoribb) megfigyelés történik, de a szabály jogalapja nem határozza meg a korrekciós intézkedéseket arra az esetre, ha a szabály tiszteletben tartásának veszélye felmerül a valós idejü mechanizmus révén.

Nincs valós idejü megfigyelés.

3/c. kritérium: A szabálytól való eltérés esetén a korrekciós mechanizmus ellenôrzéséért felelós testület jellege

(Nature of the body in charge of monitoring the correction mechanism in case of deviation from the rule)

Független intézmény (pl.: költségvetési tanács vagy megfelelő jogosultsággal rendelkező állami számvevőszék.)

Állami számvevőszék és/vagy parlament.

Pénzügyminisztérium vagy egyéb kormányzati szerv.

Nincs külön a korrekciós mechanizmusért felelös speciális testület.

3/d. kritérium: Független testület, amely makrogazdasági/költségvetési elörejelzéseket készitjjóváhagy (Independent

body providing/endorsing macro/budgetary forecasts)

Van egy független intézmény, ami biztosítja vagy jóváhagyja a makrogazdasági és költségvetési előrejelzéseket az éves költségvetés elkészítésekor.

Van egy független intézmény, ami biztosítja vagy jóváhagyja a makrogazdasági vagy költségvetési előrejelzéseket az éves költségvetés elkészítésekor.

4. kritérium: Korrekciós mechanizmusok a szabálytól való eltérés esetén (Correction mechanisms in case of deviation from the rule)

A korrekciós mechanizmus automatikusan életbe lép, és vannak előre meghatározott szabályok a korrekció természetére/méretére és/vagy időszakára vonatkozóan.

A korrekciós mechanizmus automatikusan életbe lép vagy vannak előre meghatározott szabályok a korrekció természetére/méretére és/vagy időszakára vonatkozóan.

A kormány köteles korrekciós intézkedéseket hozni vagy bemutatni a parlament vagy az illetékes hatóság felhatalmazásával, de az ilyen cselekvés előre meghatározott határidő nélküli és a beavatkozás természetére/méretre és/vagy határidejére sincsenek elöre meghatározott szabályok.

A kormány köteles korrekciós intézkedéseket hozni vagy bemutatni és a beavatkozás természetére/méretre és/vagy határidejére nincsenek elöre meghatározott szabályok.

\section{5. kritérium: A kormányzati hatáskörön kívüli sokkoknak és eseményeknek történö ellenállás képessége (Resilience to} shocks or events outside the control of the government)

Ennek a kritériumnak az értéke az igen válaszok számának összege:

Rendelkezik-e a szabály egyértelműen meghatározott mentesítő záradékkal, ami megfelel az SNP-nek?

Van-e költségvetési mozgástér a szabályhoz képest (pl.: a tervezett kiadási célok a kiadási plafonnál alacsonyabb szinten igen-1 nem-0 vannak meghatározva) vagy van-e biztonsági mozgástér a nemzeti jogszabályban rögzített MTO célhoz képest?

A célértékek ciklikusan kiigazítottak-e vagy számolják-e a ciklust valamilyen módon (pl.: a célok a ciklushoz kötöttek)? igen-1 nem-0 Vannak-e olyan kivételek a szabály alól, amelyek a hatóság ellenőrzésén kívül esnek legalább rövid távon (pl.: kamat igen-1 nem-0 fizetések, munkanélküli segélyek)?

$$
\text { Forrás: Európai Bizottság (2017) alapján saját szerkesztés }
$$

